\title{
HADITH SUTRAH: STUDY OF MA'ANIL HADITH
}

\author{
Zulfikar \\ Email: joulyasid@gmail.com \\ Islamic Communication and Broadcasting Study Program of STAI \\ Ahsanta, Indonesia
}

Abstract: This study talks about the understanding of the hadith about the sutras. I think this theme is important to discuss. To obtain a comprehensive meaning and understanding of the substance of the meaning of a hadith, in this study the author does this by considering several aspects in understanding the hadith of the Prophet SAW. such as asbabul wurud, observing variants of hadith texts, collecting meaningful traditions and looking for meanings that are relevant to the current context. In the hadith about the sutras narrated by Abu Dharr r.a, there is an order from the Prophet SAW. to make a sutrah / barrier that aims to maintain solemnity in performing prayers. If someone who prays does not make a sutrah in front of him, then his prayer will be invalid if passed by donkeys, women and black dogs. However, in the hadith narrated by Aisyah r.a, she said that she was lying in front of the Prophet SAW who was praying. Hadith regarding this sutra has a very varied meaning. According to the opinion of the majority of scholars, the hadith narrated by Abu Dharr r.a and Aisyah r.a do not contradict each other, in the hadith of A'Isyah r.a it is said that Aisyah r.a just lay in front of the Prophet SAW. who are praying, not passing.

Keyword: Ma'anil Hadith, Hadths Sutrah

\section{INTRODUCTION}

The typology of understanding Ulama' and Muslims towards hadith is classified into two parts, namely the typology of textual understanding of hadith which believes in hadith as a second source of Islamic teachings regardless of the long history of collecting hadith and the process of forming orthodoxy or what can be called the ahistorical type of thought, and the contextualist group who believes in hadith as a second source of teaching rather than Islamic teachings but with historical criticism, sees 
IJIERM: Vol. 2 No. 3 September - December 2020

and considers the background of the emergence of hadith (asbāb alwurūd). ${ }^{1}$

Among Muslims, there are not a few who seek remaining and reinterpretation of conventional fiqh texts and understandings. In this case, it is a matter of sutrah (obstacles or barriers in front of people who are praying) which is very emphasized to block the eyes of people who are praying and to prevent people from passing in front of the sutrah which can interfere with the solemnity of prayer. ${ }^{2}$ In a hadith narrated by Aisha it is said that: Rasulullah SAW mengerjakan shalat sedangkan Aisyah berbaring di hadapan beliau dan ketika Aisyah ingin bangkit dari tempat tidur maka Rasulullah SAW menarik kedua kaki Aisyah dengan lembut. This Hadith later became a problem among the Ulama'. Then what is the meaning of the barrier in the prayer itself? This hadith from Aisyah does not contradict the hadith that will be discussed in this theme. In some hadiths it is stated that if a person who prays does not use sutras and is passed by a woman, a donkey and a dog, his prayer is interrupted (void). This theme will be studied by the author, as contained in Sahīh Muslim.

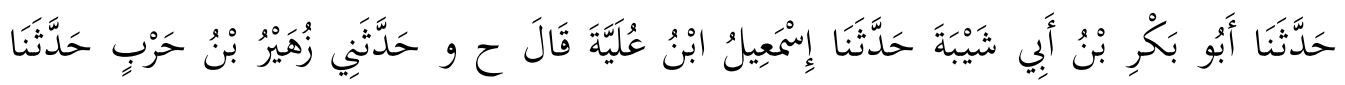

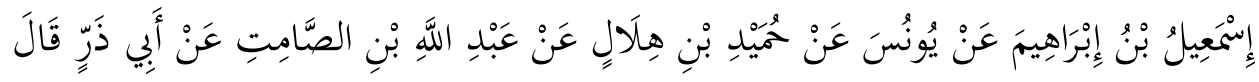

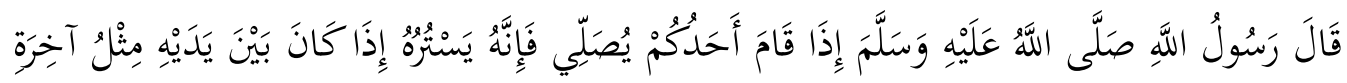

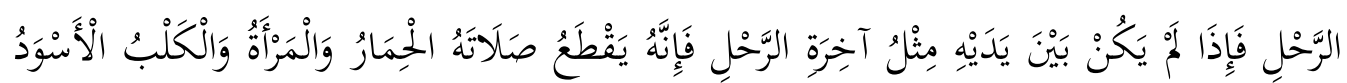

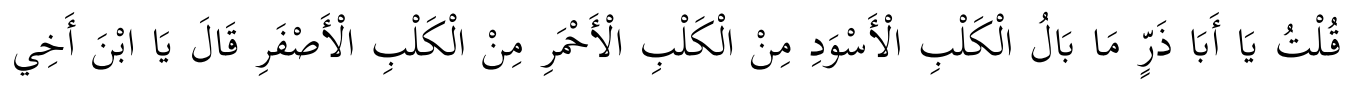

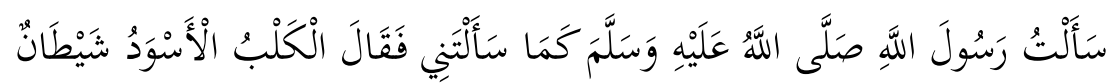

"Telah menceritakan kepada kami Abu Bakar bin Abi Syaibah telah menceritakan kepada kami Ismail Ibnu Ulayyah dia berkata, (Lewat jalur periwayatan lain) dan telah menceritakan kepadaku Zuhair bin Harb telah menceritakan kepada kami Ismail bin Ibrahim dari Yunus dari Humaid bin Hilal dari Abdullah bin ash-Shamit dari Abu Dzarr dia berkata, Rasulullah shallallahu'alaihiwasallam bersabda, "Apabila salah seorang dari kalian hendak shalat, sebaiknya kamu membuat sutrah (penghalang) di hadapannya yang berbentuk seperti kayu yang diletakkan diatas hewan tunggangan, apabila di hadapannya tidak ada sutrah seperti kayu yang diletakkan diatas hewan tunggangan, maka shalatnya akan terputus oleh keledai, wanita, dan anjing hitam.' Aku bertanya, 'Wahai Abu Dzarr, apa perbedaan anjing hitam dari anjing merah dan kuning? Dia menjawab,

1 M. Amin Abdullah, Studi Agama Normativitas atau Historisitas (Yogyakarta: Pustaka Pelajar, 1999), p. 315.

2 Sayyid Sabiq, Terjemah Fiqih Sunnah Jilid I (Jakarta: Al I'tisham Cahaya Ummat, 2010), p. 373. 
IJIERM: Vol. 2 No. 3 September - December 2020

'Aku pernah pula menanyakan hal itu kepada Rasulullah shallallahu'alaihiwasallam sebagaimana kamu menanyakannya kepadaku, maka jawab beliau, 'Anjing hitam itu setan'."

To obtain a comprehensive meaning and understanding of the substance of the meaning of a hadith, the author will conduct a search about the studied hadith starting from the activities of takhrij al-hadīs, naqd al-sanad, naqd al-matan, historical analysis, and contextualization of hadith.

\section{RESULTS AND DISCUSSION}

\section{Takhrij al-Hadis}

Apart from being the key to the treasury of hadith, takhrij al-hadith activities are carried out to get a complete picture of all hadiths that discuss the themes to be discussed. According to Abu Muhhammad Abd al-Mahdi bin Abd al-Qadir bin Abd al-Hadi there are several methods that can be used to assist in the takhrij process among them: First, according to the first lafadz of the hadith. Second, takhrij by knowing words that are rarely used by people from any part of the hadith. Third, takhrij by knowing the narrators of hadith from friends (last narrators). Fourth, according to the theme of the discussion of hadith. Fifth, according to the classification of the types of hadith. ${ }^{3}$

Of the several methods above, the author prefers the fourth method, namely according to the theme of the discussion, because the author considers that this method is the most effective way to find the hadiths in question quickly. This takhrij activity the author does only in the area of al-Kutub al-Tis'ah, and by using the mu'jam al-mufahras dictionary with keywords قطع. From these keywords the author gets the following information: 4

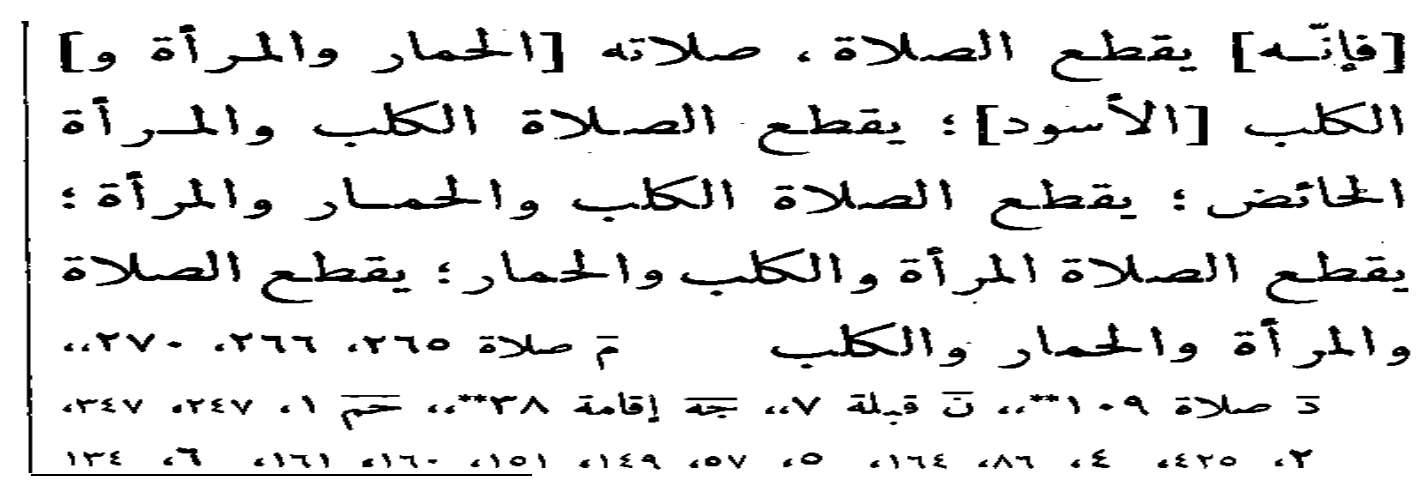

${ }_{3}$ Abu Muhammad Abdul Mahdi, Turuq Takhrïj Hadis Rasulillah, terj. Sa'id Aqil Munawwar dan Ahmad Rifqi Muchtar (Semarang: Toha Putra, 1994), p. 15.

${ }^{4}$ A.J Weisicnk, al-Mu'jam al-Mufahras Li al-Alfazh al-Hadis al-Nabawi (1965), jilid V. p. 424. 


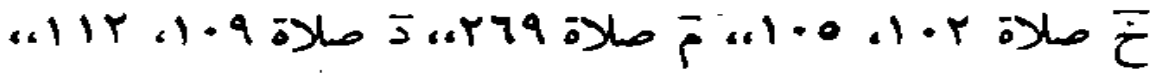 וr}

The purpose of the explanation above is, the hadith in question is contained in several books including: ${ }^{5}$

\begin{tabular}{|c|l|l|}
\hline No & \multicolumn{1}{|c|}{ Book of Hadith } & \multicolumn{1}{c|}{ Place of Hadith } \\
\hline 1 & Shahih Bukhari & Bab Shalat, nomor 102 dan 105 \\
\hline 2 & Shahih Muslim & $\begin{array}{l}\text { Bab Shalat, nomor 265,266,270 dan } \\
269,\end{array}$ \\
\hline 3 & Sunan al-Nasai & Bab Qiblat, nomor 7. \\
\hline 4 & Sunan Abi Dawud & Bab Shalat, nomor 109 dan 128 \\
\hline 5 & Sunan Ibnu Majah & Bab Iqamah, nomor 38. \\
\hline \multirow{2}{*}{6} & Musnad Ahmad bin Hanbal & $\begin{array}{l}\text { Juz I halaman, 247 dan 347. } \\
\text { Juz II halaman, 425. }\end{array}$ \\
& & $\begin{array}{l}\text { Juz IV halaman, 86 dan 164. } \\
\text { Juz VI halaman,57, 149, 151, 160, 161. }\end{array}$ \\
\hline
\end{tabular}

These hadiths are as follows:

1. Shahih Bukhari

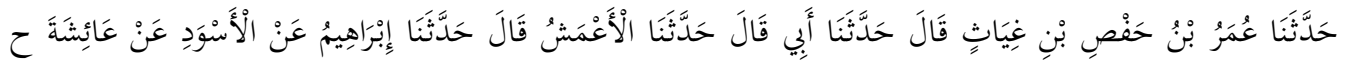

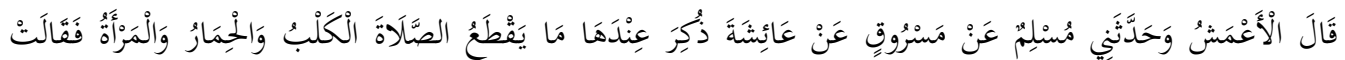

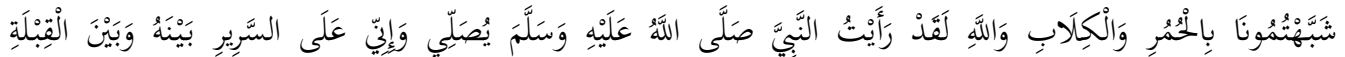

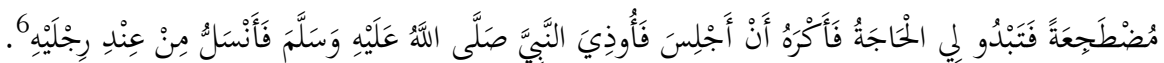

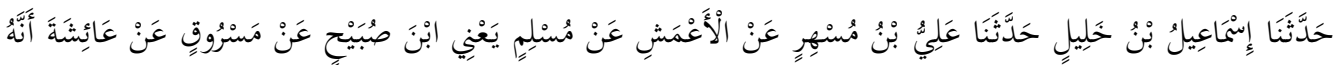

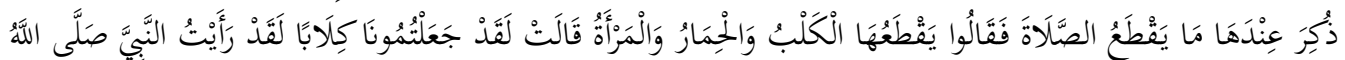

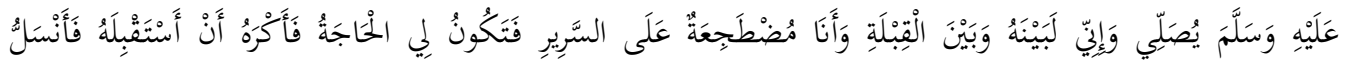

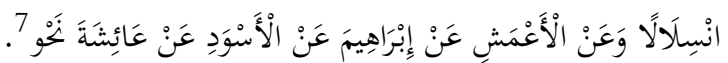

${ }^{5}$ Maksud dari syimbol-syimbol di atas adalah: Untuk Musnad ahmad (ح) hanya disebut Juz serta halamannya; untuk Shahih Muslim ( () hanya disebut bab dan nomor urut hadis; sedangkan untuk Shahih Bukhari (亡), Sunan al-Nasai (ن), Sunan Abi Daawud (د), dan Sunan Ibnu Maajah (ج) hanya disebutkan nama bab beserta nomor urut babnya. Lihat Suryadi dan Muhammad Alfatih Suryadilaga, Metodologi Penelitian Hadits (Teras: Yogyakarta, 2009), p. 44.

${ }^{6}$ Ibid. hlm. 179.

7 Abu Muhammad bin Ismail bin Ibrahim bin Al-Mughirah bin Bardizbah Al-Ju'fi Al-Bukhari, al-Jami' ash-Shahih, (Cairo: al-Matba'ah al-Salafiyah,t.t). Jilid I. Kitab Shalat, nomor hadis 511. p. 178. 
2. Shahih Muslim

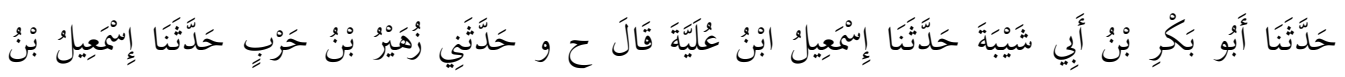

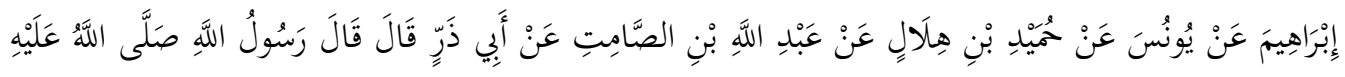

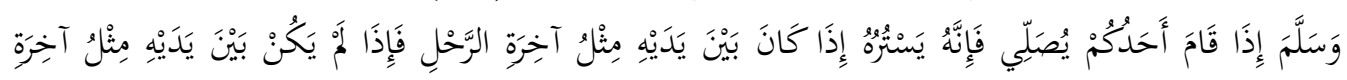

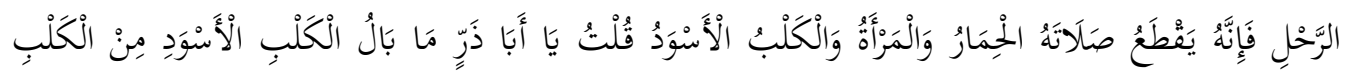

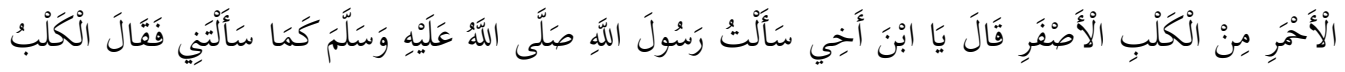

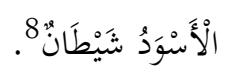

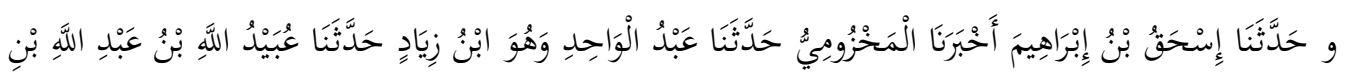

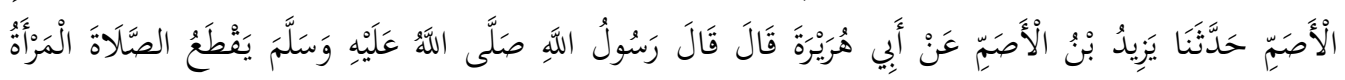

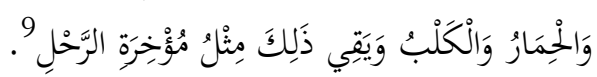

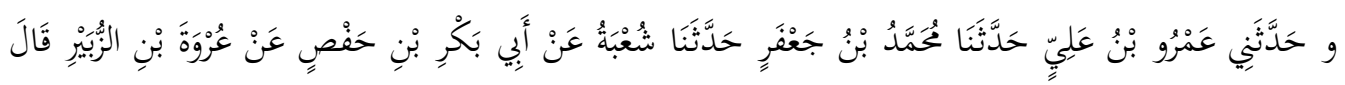

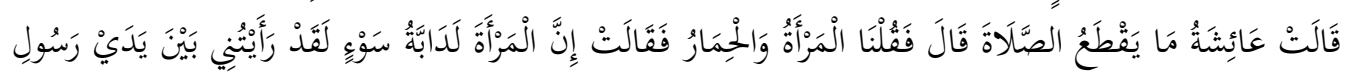

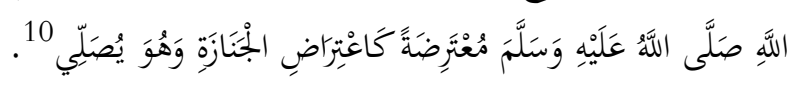

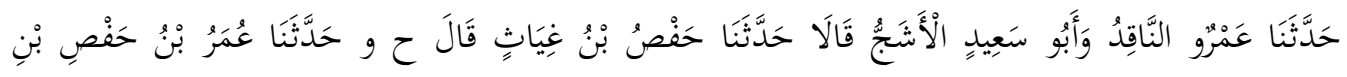

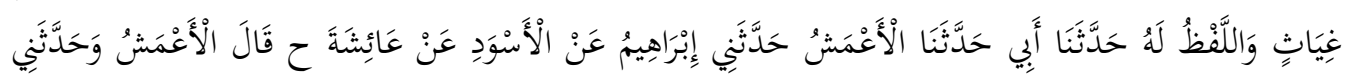

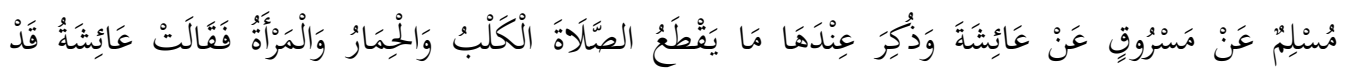

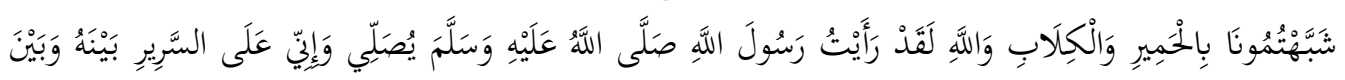

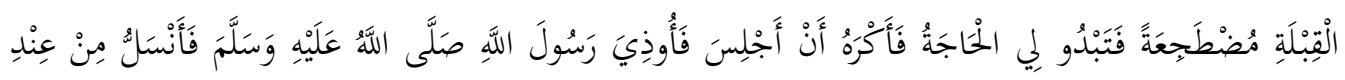
رِِجْلَيْهِ 11

3. Sunan al-Nasa'i

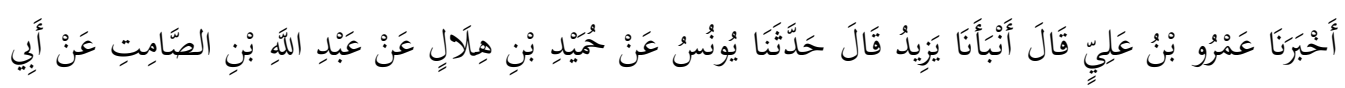

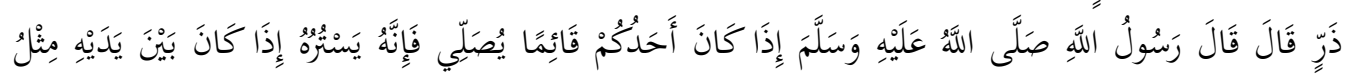

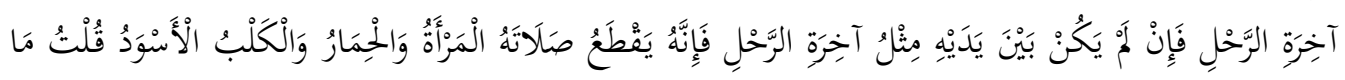

8 Abul Husain Muslim bin al-Hajjaj bin Muslim bin Kausyaz al Qusyairi an Naisaburi, Shahih Muslim, (Beirut: Dar al-Fikr,t.t). Jilid I, Kitab Shalat, Nomor Hadis 265, p. 365 .

9 Ibid. Nomor Hadis 266.

${ }_{10}$ Ibid. Nomor Hadis 269.

11 Ibid. Nomor Hadis 270. 
IJIERM: Vol. 2 No. 3 September - December 2020

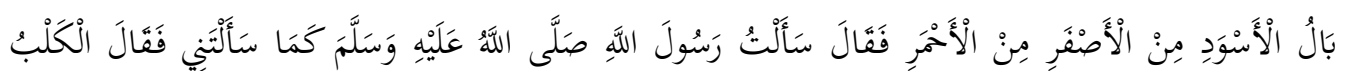

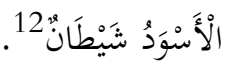

\section{Sunan Abi Daud}

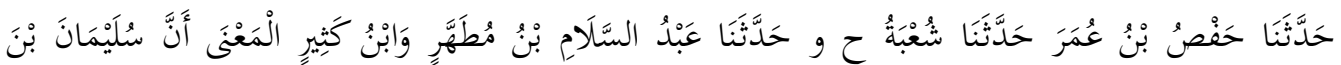

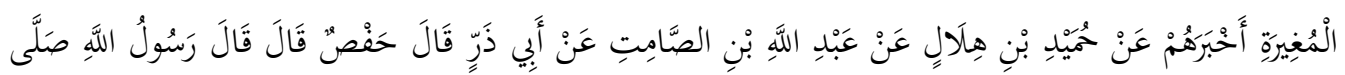

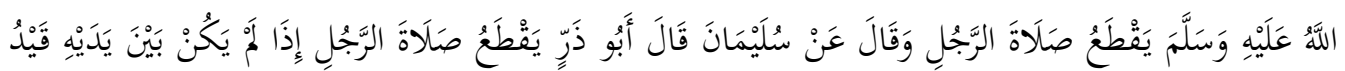

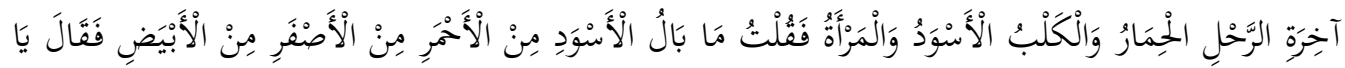

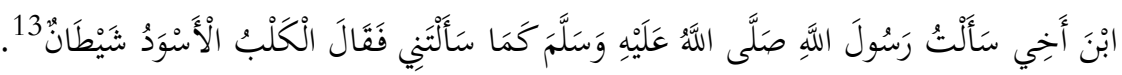

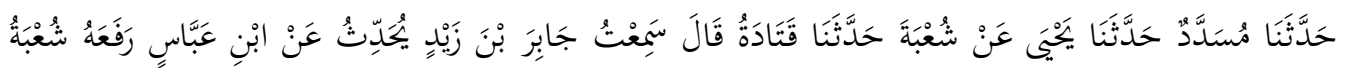

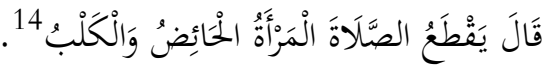

\section{Sunan Ibnu Maajah}

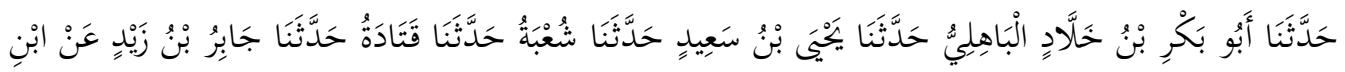

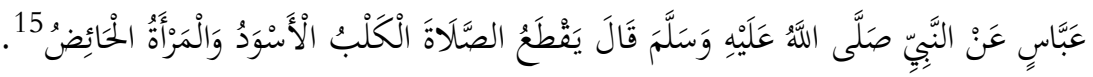

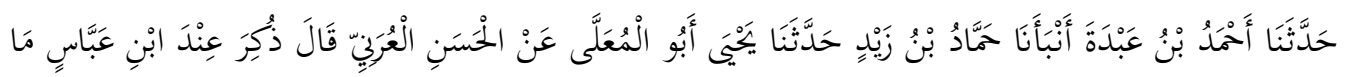

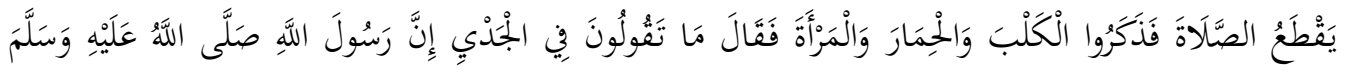

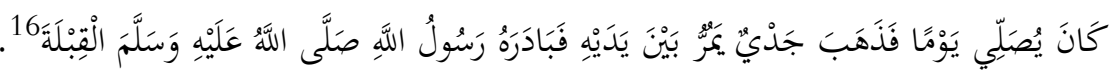

6. Musnad Ahmad bin Hanbal

From the information above, in the book of Musnad Ahmad bin Hanbal, there are 11 hadiths related to the study being researched, so that this research is not too long, the author only takes one hadith from the book of Musnad Ahmad bin Hanbal.

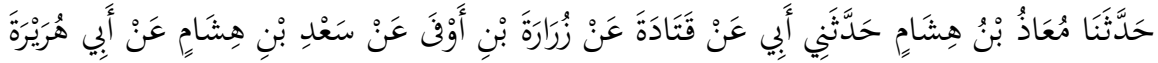

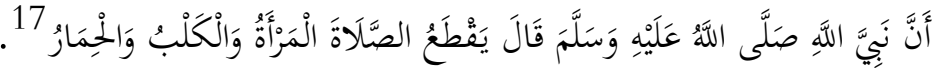

12 Abu 'Abdur Rahaman Ahmad bin Syu'aib bin 'Ali al-Kharasani alNasai, Sunan al-Nasai, (Maktab al-Mathbu' at al-Islamiyyah, t.t), Jilid II, p. 63.

13 Abu Dawud Sulaiman bin al-Asy'asy as-Sijistani al-Azdi (202-275). Sunan Abi Dawud, Beirut: Dar al-Fikr, t.t). Kitab Shalat. Hadis nomor 702. p. 125.

14 Ibid. Nomor Hadis 703.

15 Abu Abdullah Muhammad bin Yazid bin Majr ar-Rabi'i al-Qazwini, Sunan Ibnu Majah, t.t), Kitab Iqamah. Hadis nomor 949, 950,951, dan 952, p. 174.

16 Ibid. Nomor Hadis 953, p. 175 
IJIERM: Vol. 2 No. 3 September - December 2020

\section{I'tibaar Sanad}

By carrying out al-I'tibar activities, it is intended that researchers can clearly see all the paths of the sanad being studied, the names of the narrators, and the methods of narration used by each of the narrators concerned.

From the explanation above, it can be seen that the use of al-I'tibaar is to find out the condition of the entire hadith chain seen from the presence or absence of supporters (corroboration) in the form of narrators who are mutaabi 'or shaahid. What is meant by mutabi' is a narrator who is a supporter of a narrator who is not a friend of the Prophet, while what is meant by a shaahid is a narrator who has a supporting status for a friend of the Prophet SAW. Through al-i'tibaar, it will be known whether the hadiths studied have mutaabi' and shaheed or not. ${ }^{18}$

Furthermore, to simplify and clarify the process of al-i'tibar activities, it is necessary to create a scheme for all the studied sanad. There are three things that must be included in making the scheme including: the overall chain of transmissions, the names of the narrators of all the sanad, and the method of narrators used by each narrator. In the following, the author will describe the sanad scheme of each of the hadiths above.

a. The schema of the sanad from the history Bukhari

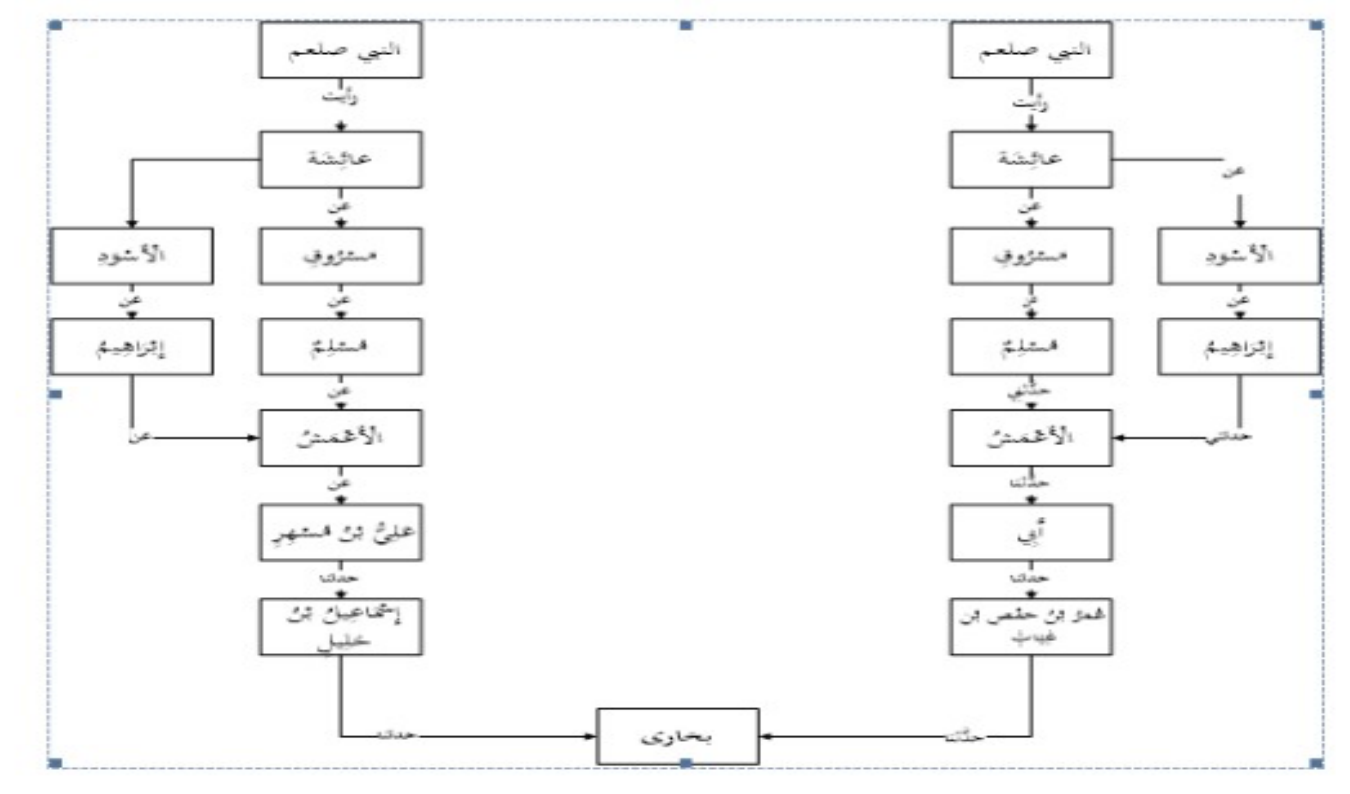

17 CD Maktabah Syamilah (versi 3,52 (2012)), [sofware komputer]. Abu 'Abdullah Ahmad bin Muhammad bin Hanbal bin Hilal bin Asad asy-Syaibani, Musnad Ahmad bin Hanbal. Jilid XXIII. Hadis nomor, 7983, p. 361.

18 M. Syuhudi Isma'il. Metodologi Penelitian Hadis Nabi (Jakarta: Bulan Bintang 1992), p. 49-50. 
IJIERM: Vol. 2 No. 3 September - December 2020

b. The schema of the sanad from the history Muslim

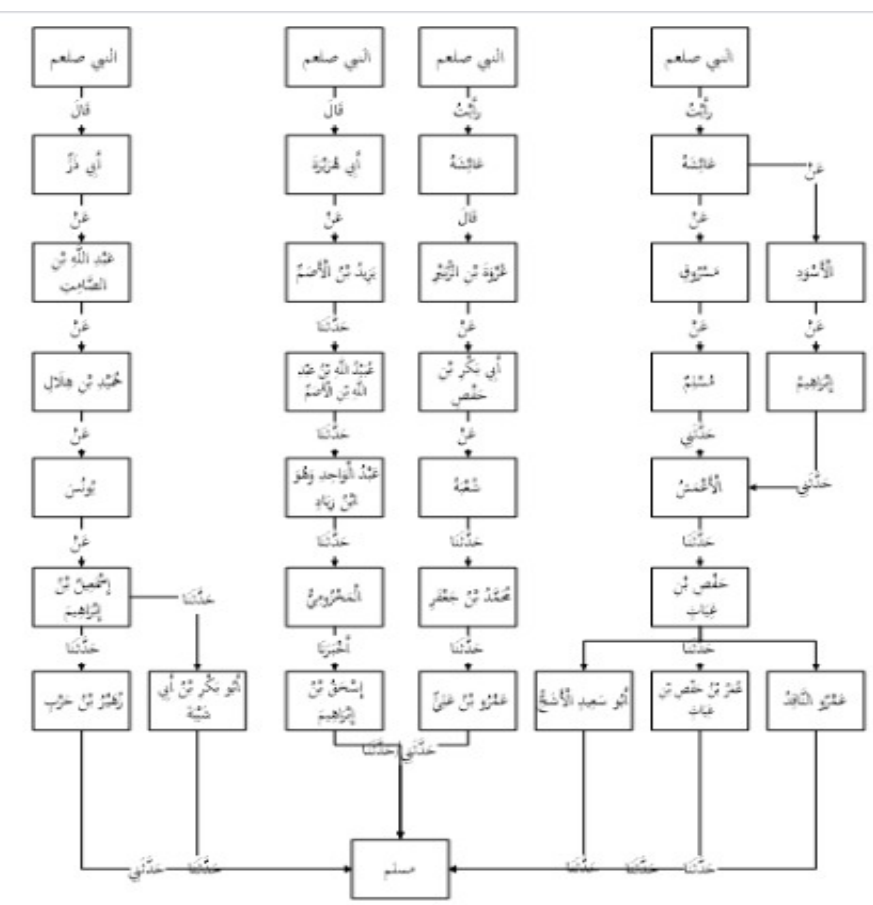

c. The schema of the sanad from the history al-Nasa'i and Ahmad bin Hanbal

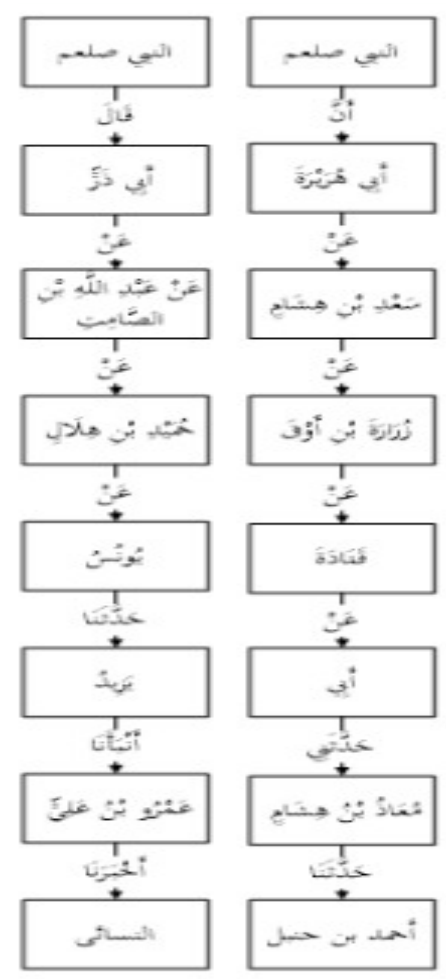


IJIERM: Vol. 2 No. 3 September - December 2020

d. The schema of the sanad from the history Abi Daawud

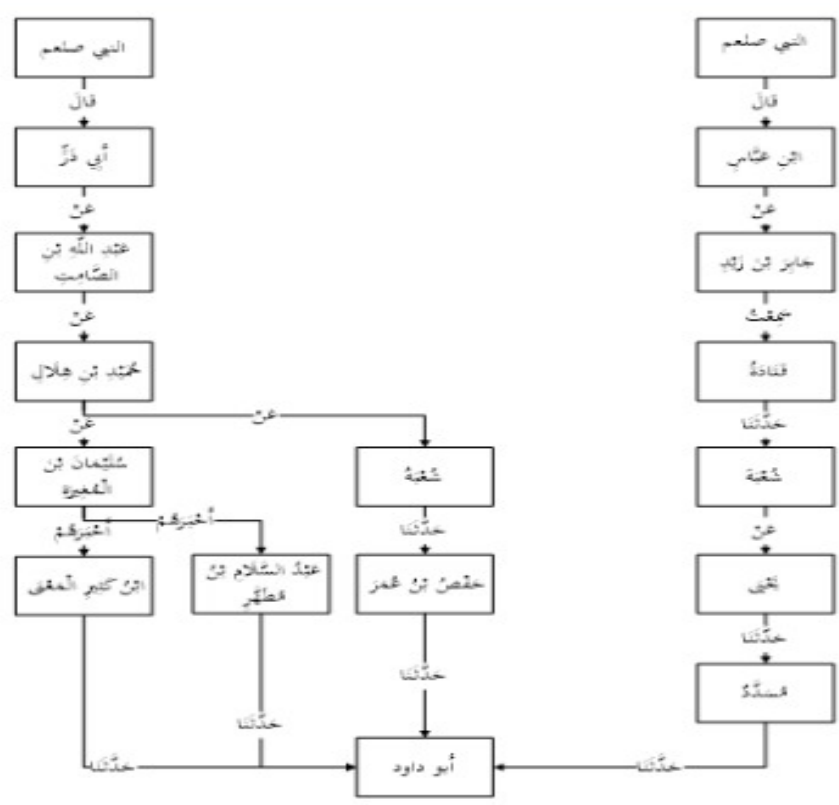

e. The schema of the sanad from the history Ibnu Maajah

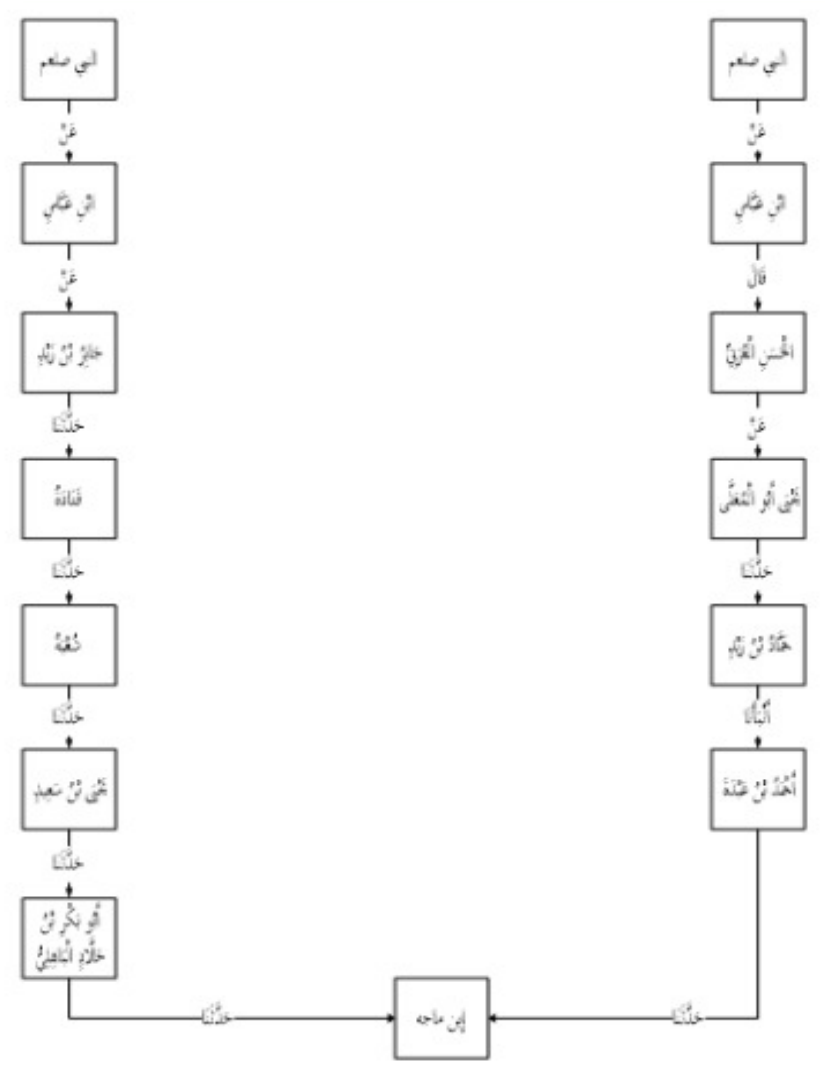


IJIERM: Vol. 2 No. 3 September - December 2020

f. Schematic of the whole sanad ${ }^{19}$

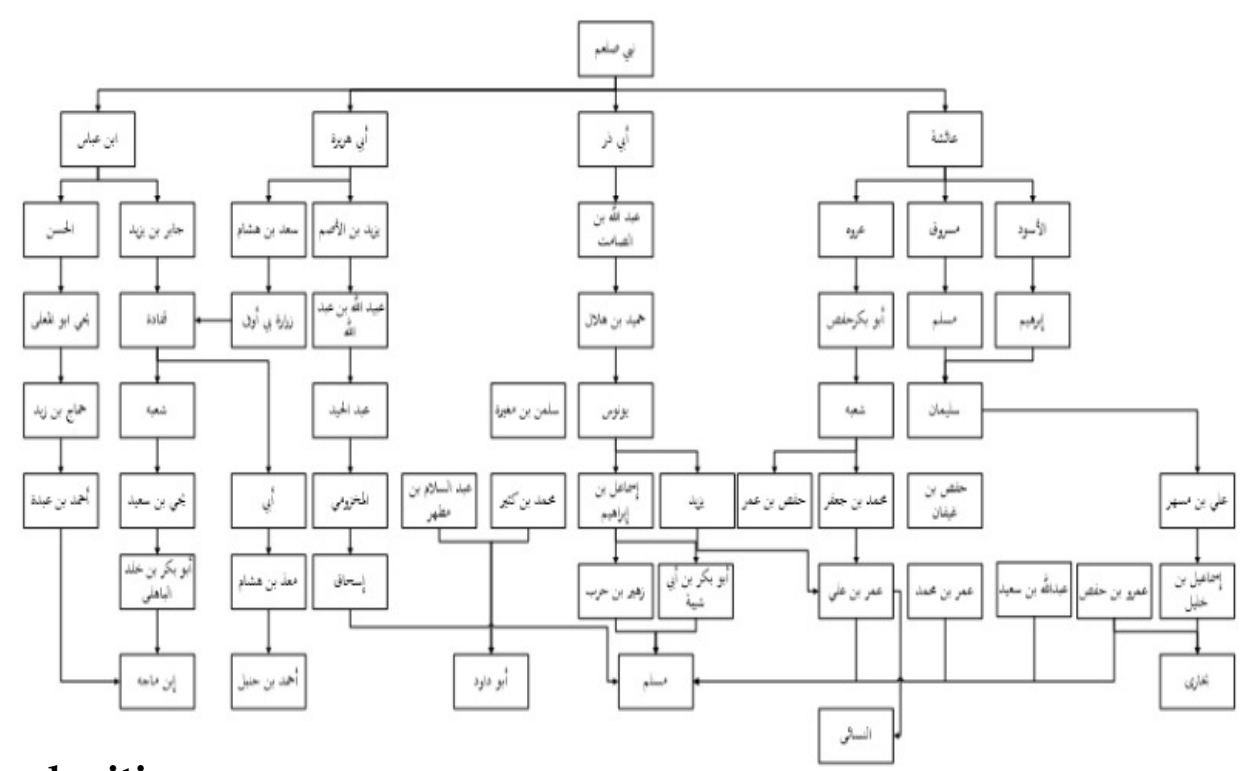

\section{Sanad critique}

From the results of the takhrij that the author has done above, it is clear that the hadith about prayers that do not use sutras will be interrupted because of three things, namely, women, donkeys and dogs. In order for this research to focus, the author will examine the hadith of Muslim history on the path of Abu Dzar. There are eight narrators on the path of Abu Dzar, including friends and mukharij, to shorten the discussion, in the criticism of this sanad, the author does not examine the sanad with mukharij status, in this case Imam Bukhari, on the grounds that he is a Mukharij whose credibility is already well known. The sanad that will be investigated in this study include:

1. Abi Dzar

Full name: Abu Dzar al-Ghifari. Sahabat Nabi SAW.

Teachers and students

- Teachers

Rasulullah SAW, Mu'aawiyah bin Abii Sufyaan

- Students

A'bdullah bin al-Shaamit, Sa'iid bin al-Musayyab, Thihfah alGhifaariy.

2. A'abdullah bin al-Shaamit

Full name: 'Abdillah bin al-Shaamit al-Ghifaariy al-Bashriy

19 Dengan alasan sistematis, maka penulis tetap memasukkan skema seluruh sanad pada bagian sub bab ini. untuk hasil yang lebih jelas mengenai skema ini, penulis lampirkan skema seluruh sanad ini pada bagian lampiran. 
IJIERM: Vol. 2 No. 3 September - December 2020

Teachers and students

- Teachers

Abu Dza al-Ghifaariy, 'Aisyah, 'Umar bin al-Khaththab.

- Students

Humaid bin Hilal al-'Adawiy, Muhammad bin Waasi', 'Amr bin Murrah. ${ }^{20}$

Comments 'Ulama

- Al-Nasaai $\rightarrow$ Tsiqah

- Abu Haatim $\rightarrow$ Yuktabu Hadiisuhu

- Ibnu Hibban mention it in the book al-Tsiqaat. ${ }^{21}$

3. Humaid bin Hilaal

Full name: Humaid bin Hilaal bin Hubairah, juga dikenal dengan nama Ibnu Suaid bin Hubairah al-'Adawiy. Designation Abu alNashr al-Bashriy.

Teachers and students

- Teachers

A'bdullah bin al-Shamit, 'Ubadan bin Qarsh, Abi Qataadah al-'Adawiy.

- Students

Yunus bin ‘Ubaid, Hisyaam bin Hassaan, 'Ashim al-Ahwal.

Comments 'Ulama

- Yahya bin Ma'iin $\rightarrow$ Tsiqah

- Al-Nasaai $\rightarrow$ Tsiqah

- Abu Haatim $\rightarrow$ Tsiqah. ${ }^{22}$

4. Yunus

Full name: Yuunus bin ‘Ubaid bin Diinaar al-'Abdiy (W. 139/140).

Designation Abu ‘Ubaid al-Bashriy.

Teachers and students

- Teachers

Humaid bin Hilal al-'Adawiy, Ibrahim al-Taimiy, al-Tsabit alBunaaniy.

- Students

Isma'il bin ‘Ulaiyah, Hatim bin Wardan, al-Hajjaj bin al-Hajjaj.

20 Jamal al-Din Yusuf al-Mizzi, Tahdzib al-Kamal Fi Asma al-Rijal, Jilid XXXIII Beirut : Darul Fikr, 1994 ), p. 294,295.

21 Jamal al-Din Yusuf al-Mizzi, Tahdzib al-Kamal..., Jilid XV ( Beirut : Darul Fikr, 1994 ), p.120-121.

22 Jamal al-Din Yusuf al-Mizzi, Tahdzib al-Kamal..., Jilid VII (Beirut : Darul Fikr, 1994), p 403-406. 
IJIERM: Vol. 2 No. 3 September - December 2020

Comments 'Ulama

- Muhammad bin Sa'ad mention it in the fourth thabaqah of the Basrah $\rightarrow$ Tsiqah narrates many hadiths

- Ahmad bin Hanbal $\rightarrow$ Tsiqah

- 'Ali ibn al-Madini $>\rightarrow$ Atsbat. $^{23}$

5. Ismail bin Ibrahim

Full name: Ismail bin Ibrahim bin Miqsam al-Asadiy, yang terkenal dengan Ibn ‘Ulayyah. (110-193)

Teachers and students

- Teachers

Yuunuus bin 'Ubaid, Waliid bin Abi Hisyaam, Yahya bin 'Atiiq.

- Students

Zuhair bin Harb, Syu'bah bin al-Hajjaaj, Daaud bin Rusyaid.

Comments ‘Ulama

- 'Ali ibn al-Madiinii $\rightarrow$ Astbat min Wuhaib

- Yahya bin Ma'iin $\rightarrow$ Tsiqah Ma'Muun

- Al-Nasaii $\rightarrow$ Tsiqah Tsabat. ${ }^{24}$

6. Zuhair bin Harb

Full name: Zuhair bin Harb bin Syaddad al-Harasyi.

Teachers and students

- Teachers

Ismail bin 'Ulaiyyah, Ahmad bin Ishaq al-Hadhramiy, Habban bin Hilal.

- Students

Muslim, Bukhari, Abi Daud.

Comments 'Ulama

- Yahya bin Ma'in $\rightarrow$ Tsiqah

- Ya'qub bin Syabah $\rightarrow$ Astbat

- Abu Bakar al-Khathib $\rightarrow$ Tsiqah Tsabat Hafizhan Mutqinan.

7. Abu Bakr bin Abi Syaibah

Full name: 'Abdullah bin Muhammad bin Ibrahim bin 'Utsman bin Khawasitiy al-'Absiy. Better known as Ibn Ab Syaibah al'Absyiy. Designation Abu Bakar (W. 235).

${ }^{23}$ Jamal al-Din Yusuf al-Mizzi, Tahdzib al-Kamal..., Jilid XXXII (Beirut : Darul Fikr, 1994), p. 517-533.

24 Jamal al-Din Yusuf al-Mizzi, Tahdzib al-Kamal..., Jilid III (Beirut : Darul Fikr, 1994), p. 23-31. 
IJIERM: Vol. 2 No. 3 September - December 2020

Teachers and students

- Teachers

Ismail bin 'Ulaiyyah, Ismail bin 'Iyasy, Ja'far bin 'Awn

- Students

Muslim, Bukhari, Abi Daud.

a. Comments 'Ulama'

- Al-'Ijli $\rightarrow$ Tsiqah

- Abu Hatim $\rightarrow$ Tsiqah ${ }^{25}$

After looking at the information above, it can be seen that all the hadith narrators on the Abi Dzar line above are tsiqah and their sanad is continued from the source of the hadith, namely the Prophet SAW. to the last Muslim narrator who is also his mukhaarij. This means that the hadiths studied on the Abi Dzar route have the status of sahih al-sanad.

\section{Matan Criticism}

Internal criticism or better known as criticism of matan or naqd almatn, the scholars have formulated two criteria, namely avoiding syadz and illah, the criteria for syadz and illah in matan are explained by Salah al-Din al-Adlabi in his book Manhaj Naqd al -Matn 'Inda 'Ulama al-Hadith al-Nabawi into four criteria, namely: not contradicting the verses of the Koran; does not conflict with a more authentic hadith; does not conflict with reason, senses and history; and resemble the words of the Prophet. ${ }^{26}$

In this study, the author will use the theory of internal criticism offered by Al-Adlabi above:

1. Does not conflict with the verses of the Qur'an

The Qur'an is the first normative source in Islamic teachings, while the hadith occupies the second position after the Qur'an, therefore it has become one of the requirements for authenticity of the hadith is not contrary to the Qur'an which is qath'i.

With regard to the hadith that is being studied in this paper, in the opinion of the author, this hadith does not conflict with the verse of the Qur'an, the author does not find any verse of the Qur'an that indicates that it is contrary to the hadith.

${ }^{25}$ Jamal al-Din Yusuf al-Mizzi, Tahdzib al-Kamal..., Jilid XVI ( Beirut: Darul Fikr, 1994), p. 32-41.

${ }^{26}$ Lihat Shalah Al-Din Al-Adlabi, Manhaj Naqd Al-Matn 'Inda 'Ulama Al-Hadis AlNabawi, (Beirut: Dar al-Faq al-Jadidah, 1983). 
2. Does not conflict with the more authentic hadith

One of the conditions for authentic hadith in terms of maturity is that the hadith does not conflict with a more authentic hadith. In this study, the hadiths that have been pre-determined above do seem contradictory between those indicating that prayer is invalidated if a woman, a donkey, and a dog pass through it if there is no sutrah in front of it, and there is also an indication that it is not invalidated. On the surface, it appears that these hadiths contradict each other, but if you look closely, they do not contradict each other, because the context of each hadith is different. The difference in context that the author means here will be explained in the sub-chapter Contextualization of Hadith.

3. Does not conflict with reason and historical facts

The Qur'an has confirmed that what was said by the Prophet SAW. not the will of his lust, but what the Prophet SAW said. on the guidance or revelation of Allah SWT. therefore, if a hadith that really comes from the Prophet SAW. could not contradict common sense and historical facts. With regard to the hadith being studied at this time, according to the writer, this hadith does not contradict common sense and historical facts. A review of this will be discussed by the author in the sub-chapter on Meaning of Hadith.

4. Resembling the words of the Prophet SAW Nabi

Including one of the conditions for a valid hadith in matan is that the hadith indicates that the hadith resembles the words or words of the Prophet SAW. Departing from the information above, the author concludes that the hadith on the Abi Dzar path is protected from syadz and 'illah, and has met the criteria for a valid hadith, and according to the author of the hadith on the Abi Dzar path, the status is Sahih, both in terms of sanad and matan.

\section{Meaning of Hadith}

In this study, the author makes the hadith narrated by Imam Muslim Imam from the path of Abi Dzar as the main reference, of course supported and strengthened by other narrations such as narrations from Imam Bukhari, Imam Ahmad, Imam Abu Dawud, Imam An Nasa'i, Imam Al Nasa'i and Imam Ibn Majah.

Hadith about Lintasan Tanpa Sutrah Tidak Membatalkan Shalat Kecuali Lintasan Anjing, keledai, Wanita has a very varied meaning, making it difficult for some Muslims to know the substance of the meaning referred 
to in this hadith. Therefore, in order to get a complete meaning of this hadith, the scholars tried to provide an explanation and guidance as follows: Sayyid Sabiq explained that walking in front of people who are praying and in the sutras is haram and is a major sin. This opinion is based on the hadith of the Prophet narrated by Busr bin Sa'id which narrates that Zaid bin Khalid once sent him to Abu Juhaym to ask about what he had heard from the Prophet Muhammad regarding the law of passing in front of people who were praying. ${ }^{27}$

M. Musthafa Al A'dzami in book Shahih Ibnu Khuzaimah explained that the hadith that describes a woman who passes when someone is praying does not contradict the hadith of Ayesha, because the Prophet's intention was that the crossing of a dog, a woman and a donkey invalidated the prayer, not the silence of the dog or the roaring of the donkey or the lying down of the woman who broke the prayer. While Aisyah narrated that she was lying in front of the Prophet SAW who was praying and not passing in front of him. It is also explained that what is meant by women being equal to black dogs and donkeys in canceling prayer is a woman who is menstruating and it is explained in the hadith of Abu Dzar that the dog who cancels prayer is a black dog and not another dog..$^{28}$

Imam An-Nawawi said: There are various opinions of scholars: Jumhur Al-Ulama among the Salaf (Initial) and Khalaf (Later), Imam Abu Hanafi, Imam Maliki and Imam Shafii say that prayer is not invalidated because it is crossed by the three types above. When Imam Ahmad bin Hanbal said it would be canceled if a black dog crossed him, but he was not sure about the cancellation because of two other types because when the Prophet SAW was praying, Ayesha was sleeping in front of him in the direction of the Qibla, while the Prophet continued his prayer.

\section{Historical Analysis}

Asbabul wurud hadith will lead to contextual understanding of hadith, but not all hadiths have asbabul wurudnya. Knowledge of the context of a hadith cannot guarantee a common understanding of every hadith observer. According to Komaruddin Hidayat, this is due to the condition of the hadiths which are generally contextual and situational interpretations of the verses of the Qur'an in response to the friend's questions. Therefore, according to him, the understanding

${ }^{27}$ Sayyid Sabiq, Terjemah Fiqih Sunnah Jilid I. p.376.

28 M. Musthafa Al A'dzami, Terjemah Sahih Ibnu Khuzaimah (Jakarta: Pustaka Azzam, 2008), p.41-42. 
of scholars who know the life history of the Apostle will be different from those who do not know it. In addition, the historical content in detail has been greatly reduced, so that in history there are often differences in information.

Asbab al-wurud is the historical context, either in the form of events or questions or others that occurred at the time the hadith was delivered by the Prophet Muhammad. It can serve as an analytical knife to determine whether the hadith is general or specific, absolute or muqayyad, nasikh or mansukh or something else.

Thus, knowing asbab al-wurud is very significant for obtaining a comprehensive understanding of the meaning and moral message of a hadith. If no specific (micro) asbab al-wurud is found, then as an alternative you can use a macro approach, namely by paying attention to historical, sociological, anthropological, or even psychological aspects. This is based on an assumption that the Prophet SAW could not speak in a historical vacuum and cultural vacuum. As ideas, ideas, including the words of the Prophet, will always be based on historical facts. In other words, he must be tied to the historical-cultural problems of that time. ${ }^{29}$

Hadith about Lintasan Tanpa Sutrah Tidak Membatalkan Shalat Kecuali Lintasan Anjing, keledai, Wanita In this case, no specific (micro) asbab alwurud was found, but it may have something to do with the sociohistorical conditions at that time or by looking at the macro asbab alwurud. From the asbab al-wurud macro, it is possible that the hadith relates to the order to limit the time of prayer as a sign for people who want to pass in front of it and limit the eyes of those who want to pray. ${ }^{30}$ There are many hadiths that discuss the sutras. Then there is a hadith that relates to what happened to Ayesha when the Prophet prayed in front of her while Ayesha was sleeping. This will have something to do with the hadith discussed by the author, namely Lintasan Tanpa Sutrah Tidak Membatalkan Shalat Kecuali Lintasan Anjing, keledai, Wanita. But here Ayesha does not cross the position of the prayer but is sleeping, if it passes, then her prayer is invalid. But there is a hadith narrated by Abdurrahman from Malik where at that time Malik passed in front of the people who were praying while at that time Malik was riding a donkey and the Prophet did not order the praying people to repeat his prayer. Why the Prophet did not order to repeat his prayer is because in this hadith there is no information that the Prophet saw the donkey passing between the rows of

${ }^{29} \mathrm{Ibid}$, p. 6.

30Sayyid Sabiq, Terjemah Fiqih Sunnah Jilid 1. p.372. 
IJIERM: Vol. 2 No. 3 September - December 2020

prayer and also the Prophet did not know the case for sure because in another narration it is also narrated from Ibn Abbas which when the Prophet was During the prayer, Ibn Abbas passed in front of the Prophet while at that time Ibn Abbas was riding a donkey and the Prophet also did not order to repeat his prayer, but this hadith also has no clear explanation. However, if you look at Ibn Abbas' statement, it can be seen that the hadith lafadz states that Ibn Abbas passed in front of the Prophet after getting off the donkey because he said "kemudian aku melintas di hadapan Nabi yang sedang shalat". ${ }^{31}$

\section{Contextualization of Hadith}

Hadith, which is called the second source of law after the Qur'an, has gone through a long journey, not only in codifying and researching its validity, but also developing the right "meaning" for a hadith that can ground the universality of Islamic teachings. The meaning of hadith is a complicated problem. The meaning of the hadith is carried out on the hadith whose validity is clear, at least the traditions that are categorized as hasan.

In the meaning of hadith, it is necessary to clarify whether a hadith will be interpreted textually or contextually. Understanding of the content of the hadith whether a hadith belongs to the category of temporal, local or universal, as well as whether the context relates to the personal pronunciation only or includes the interlocutor social conditions when the text appears.

From the various problems of understanding hadith globally, the author examines and examines the correct meaning and understanding of the hadiths about the interruption of prayer due to the passage of dogs, donkeys and women in the absence of sutrah..

Initial identification is what the meaning of prayer is and how to perform the prayer according to the provisions of the Shari'a, including things that can invalidate the Salat according to the Shari'a. The fuqaha give the meaning of prayer is

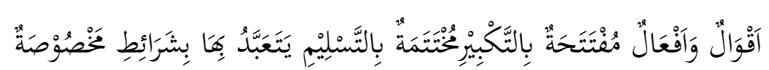

"Beberapa ucapan dan beberapa perbuatan yang dimulai dengan takbir, disudahi dengan salam, yang dengannya kita beribadat kepada Allah, menurut syarat-syarat yang ditentukan".

${ }^{31}$ M. Musthafa Al A'dzami, Terjemah Sahih Ibnu Khuzaimah. p.45-46. 
Salat is a ritual of worship for Muslims as an effort to get closer to Allah and manifest piety to the Divine Rabbi. In salat There are rules for its implementation in accordance with the provisions of the Shari'a, including the conditions for the validity of the prayer, the pillars of prayer and things that can invalidate the prayer. The conditions for a valid prayer are knowing that the time for prayer has entered, being pure from major and minor hadas, being clean of the body, clothing and place of prayer, covering the aurat and facing the Qibla.

In addition, there are several things that invalidate the prayer, namely eating, drinking intentionally, speaking deliberately not for the benefit of prayer, doing a lot of work intentionally, leaving (damaging) a pillar or condition on purpose and there is no excuse. But on the other hand there are also several hadiths that explain that prayers can be interrupted because of the passage of dogs, donkeys and women.

By looking at the hadith above, it is necessary to find the right meaning of the hadith. The problem is whether the crossing of dogs, donkeys and women can break the prayer (cancel the prayer). The position of these traditions is valid so that the next problem is to provide an appropriate, proportional and representative meaning of the hadith. Will a valid hadith always be representative to be used as evidence which can then be applied in contemporary reality.

Thus, the most urgent problem is that at first glance there is a difference in what is explained by the provisions of the Shari'a regarding things that can invalidate prayer and the hadith statement that prayers can be interrupted because of the passage of dogs, donkeys and women. Thus, how should the hadith be understood textually or contextually and the content of the hadith is temporal, local or universal. In the editorial of the hadith, why only the passing of dogs, donkeys and women can decide the prayer. Why is this devoted to these three things, what exactly are the variables contained behind the text. For this reason, this hadith is investigated further.

According to the author himself, what is meant by his prayer being interrupted is that his intention is interrupted because he has hesitated in performing his prayer. It is sunnah to prevent people from passing in front of the one who is praying, but if the one who is praying does not put the sutra and someone passes in front of him, it is not the fault of the passer-by, neither is the woman. Sometimes people who pass by don't know that someone is praying because there is no sutrah in front of him. 
IJIERM: Vol. 2 No. 3 September - December 2020

If it is applied to the present, it is less relevant because not all mosques have a sutrah, if the mosque is full and there is no other way but to pass in front of people who are praying then it is not the fault of the person who passes by and this person's prayer is not canceled even though there are people who pass by, now there are no donkeys anymore because people's vehicles now no longer use donkey services but have been replaced with motorized vehicles, if it is forbidden for a woman who is menstruating to enter the mosque because she is worried that her blood will drip, then that concern has been resolved with the progress of the current era. So if the person's prayer is disturbed, then the prayer is invalid, but if it is not disturbed then it is not invalidated.

\section{CONCLUSION}

From the explanation above, the following conclusions can be drawn: First, the hadith narrated by Imam Muslim from Abi Dzar has several variations in the form of matan. Second, after doing criticism of sanad and criticism of matan, then this hadith is categorized as authentic hadith.

Third, M. Musthafa Al-A'dzami in the book Sahih Ibn Khuzaimah explains that the hadith that describes a woman who passes when someone is praying does not contradict the hadith of Ayesha, because the Prophet's intention was that the crossing of dogs, women and donkeys invalidated the prayer, not silence. The dog or the roar of the donkey or the lying down of the woman who invalidates the prayer. While Aisyah told that she was lying in front of the Prophet who was praying and not passing in front of him. It is also explained that what is meant by women being equated with black dogs and donkeys in canceling prayer is a woman who is menstruating, and it is explained in this hadith from the path of Abi Dharr that the dog who cancels prayer is a black dog and not another dog. 
IJIERM: Vol. 2 No. 3 September - December 2020

\section{Bibliography}

Abdullah, M. Amin, Studi Agama Normativitas atau Historisitas, Yogyakarta: Pustaka Pelajar, 1999.

Abu 'Abdur Rahaman Ahmad bin Syu'aib bin 'Ali al-Kharasani al-Nasai, Sunan al-Nasai, Maktab al-Mathbu'at al-Islamiyyah, t.t.

Abu Abdullah Muhammad bin Yazid bin Majr ar-Rabi'i al-Qazwini, Sunan Ibnu Majah, t.t.

Abu Muhammad bin Ismail bin Ibrahim bin Al-Mughirah bin Bardizbah Al-Ju'fi Al-Bukhari, al-Jami' ash-Shahih, Cairo: al-Matba'ah alSalafiyah, t.t.

Abu Dawud Sulaiman bin al-Asy'asy as-Sijistani al-Azdi. Sunan Abi Dawud, Beirut: Dar al-Fikr, t.t.

Abul Husain Muslim bin al-Hajjaj bin Muslim bin Kausyaz al Qusyairi an Naisaburi, Shahih Muslim, Beirut: Dar al-Fikr,t.t.

Al A'dzami, M. Musthafa, Terjemah Sahih Ibnu Khuzaimah, Jakarta:Pustaka Azzam, 2008.

Al-Adlabi, Shalah Al-Din Manhaj Naqd Al-Matn 'Inda 'Ulama Al-Hadis AlNabawi, Beirut: Dar al-Faq al-Jadidah, 1983.

CD Maktabah Syamilah, versi 3,52, 2012, sofware komputer. Abu 'Abdullah Ahmad bin Muhammad bin Hanbal bin Hilal bin Asad asy-Syaibani, Musnad Ahmad bin Hanbal.

Isma'il, M. Syuhudi, Metodologi Penelitian Hadis Nabi. Jakarta: Bulan Bintang 1992.

Jamal al-Din Yusuf al-Mizzi, Tahdzib al-Kamal Fi Asma al-Rijal, Jilid XXXIII, Beirut : Darul Fikr, 1994.

Mustaqim, Sa'id HusinAgil Munawwar dan Abdul,Asbab al-Wurūd, Yogyakrta: Pustaka Pelajar, 2001).

Sa'id Aqil Munawwar dan Ahmad Rifqi Muchtar, Semarang: Toha Putra, 1994.

Sabiq, Sayyid, Terjemah Fiqih Sunnah Jilid I (Jakarta: Al I'tisham Cahaya Ummat, 2010).

Suryadi dan Muhammad Alfatih Suryadilaga, Metodologi Penelitian Hadits, Teras: Yogyakarta, 2009.

Weisicnk, A.J, al-Mu'jam al-Mufahras Li al-Alfa>zh al-Hadis al-Nabawi, 1965, jilid $\mathrm{V}$. 